\title{
Reinfections with strains of Trypanosoma cruzi, of different biodemes as a factor of aggravation of myocarditis and myositis in mice
}

\author{
Reinfecções com cepas do Trypanosoma cruzi de diferentes biodemas como fator \\ agravante da miocardite e miosite em camundongos
}

\author{
Sonia Gumes Andrade ${ }^{1}$, Rozália Figueira Campos ${ }^{1,2}$, Karina Souza Castro Sobral $^{1}$, \\ Juracy Barbosa Magalhães ${ }^{1}$, Ricardo S. Pereira Guedes ${ }^{1}$ and Marcos Lázaro Guerreiro ${ }^{1,2}$
}

\begin{abstract}
Reinfections with Trypanosoma cruzi in patients from endemic areas have been claimed to be an aggravation factor of cardiac manifestations in Chagas' disease. In the present study, the influence of triple infections with strains of different biodemes, on cardiac and skeletal muscle lesions was experimentally tested. Fifty eight mice chronically infected with the Colombian strain (Biodeme Type III) were successively reinfected as follows: $1^{\text {st }}$ group - reinfected with 21 SF strain (Type II) followed by $Y$ strain (Type I); $2^{\text {nd }}$ group - reinfections with Y strain followed by $21 S F$ strain. Isoenzyme analysis of parasites from hemocultures obtained from triple infected mice, revealed the patterns of three distinct zymodemes in the same animal. Each Trypanosoma cruzi strain was reisolated after four passages in mice on either the $7^{\text {th }}, 14^{\text {th }}$ or $30^{\text {th }}$ day after inoculation with the blood of triple infected mice. Histopathology results demonstrated a significant exacerbation of cardiac and skeletal muscle inflammatory lesions, confirmed by morphometric evaluation, in mice with triple infection. No aggravation of parasitism was detected. The possibility of an enhancement of cellular response in the triple infected mice is suggested.
\end{abstract}

Key-words: Biodemes. Chagas' disease. Reinfections. Trypanosoma cruzi. Zymodemes.

\section{RESUMO}

Reinfecções pelo Trypanosoma cruzi em pacientes de áreas endêmicas têm sido mencionadas como fator agravante das manifestações cardíacas na doença de Chagas. No presente estudo, a influência da tríplice infecção com cepas de diferentes biodemas, sobre as lesões do miocárdio e de músculo esquelético foi investigada experimentalmente. Cinqüenta e oito camundongos cronicamente infectados com a cepa Colombiana do Trypanosoma cruzi (Biodema Tipo III) foram sucessivamente reinoculadas como a seguir: $1^{\circ}$ grupo - reinfectados com a cepa 21 SF (Tipo II) seguido pela cepa Y (Tipo I); $2^{\circ}$ grupo reinfecção com a cepa $Y$ seguida pela cepa 21SF. A análise isoenzimática dos parasitas das hemoculturas obtidas dos animais com tríplice infecção, revelou os padrões dos diferentes zimodemas no mesmo animal. Cada cepa do Trypanosoma cruzi foi re-isolada após quatro passagens em camundongos no $7^{\circ}$, no $14^{\circ}$, ou no $30^{\circ}$ dia após a inoculação com o sangue de camundongos com tríplice infecção. Resultados da histopatologia demonstraram uma significante exacerbação das lesões inflamatórias de miocárdio e músculo esquelético, confirmadas pela avaliação morfométrica. Não foi detectada acentuação do parasitismo. A possibilidade de aumento da resposta celular nos animais com tríplice infecção é sugerida.

Palavras-chaves: Biodemas. Doença de Chagas. Reinfecções. Trypanosoma cruzi. Zimodemas.

\footnotetext{
1.Laboratório de Chagas Experimental, Autoimunidade e Imunologia Celular do Centro de Pesquisas Gonçalo Moniz da Fundação Oswaldo Cruz. Salvador, BA. 2. Departamento de Ciências Biológicas da Universidade Estadual de Feira de Santana, Feira de Santana, BA, Brasil.

Address to: Dra. Sonia G. Andrade. Centro de Pesquisas Gonçalo Moniz/FIOCRUZ. Rua Waldemar Falcão 121, Brotas, 40295-001 Salvador, BA, Brasil.

e-mail: sgandrade@cpqgm.fiocruz.br

Recebido para publicação em 08/04/2005

Aceito em 23/11/2005
} 
Early studies on the clinical manifestations in patients chronically infected with Trypanosoma cruzi, in endemic areas, emphasized the importance of reinfections in the maintenance of parasitism and in the severity of cardiac lesions ${ }^{10}$. Epidemiological observations by Dias ${ }^{13}$ in Bambuí, MG and Macedo ${ }^{16}$ in São Felipe, BA, comparing the incidence and severity of cardiac disease in areas in which the vector has been eliminated, have confirmed these impressions.

Experimentally, different authors have studied the influence of reinfections and the results pointed to the development of a resistance after a first infection ${ }^{2891125}$. This resistance avoids the development of an acute phase of reinfection with a virulent strain as shown by Andrade et $\mathrm{al}^{3}$ who reinoculated with the $\mathrm{Y}$ strain, mice chronically infected with the Colombian strain. However, an important aspect emerged from the experimental studies, the demonstration of persistence, and the possibility of the identification of $T$. cruzi strains inoculated in mice previously infected with a different $\operatorname{strain}^{2312}$. These results indicate that the resistance conferred by a previous infection is partial and does not prevent the development of the parasites of a new inoculation.

The question remains whether the persistence of parasites of multiple infections with strains of different biodemes, influences the evolution and intensity of cardiac lesions in the chronic phase of infection.

In the present study an investigation into the influence of multiple inoculations in the pathology of experimental infection in mice was realized. Three strains, prototypes of three different biodemes Types: I (Y strain), II (21SF strain) and III (Colombian strain) as described by Andrade ${ }^{1}$, and Andrade \& Magalhães ${ }^{4}$, were used. Considering their pathogenicity and tissue tropism, an evaluation of the intensity of the tissue lesions determined in the experimental mice submitted to multiple infections was performed. The reactivation of each strain reisolated from mice with triple infection revealed the maintenance of their virulence and pathogenicity for naïve mice and permitted the realization of their biological and isoenzyme characterization. We believe it is of clinical interest to investigate the potential to produce lesions with a combination of strains of three different biodemes in the experimental model.

\section{MATERIAL AND METHODS}

Experimental animals. Swiss Webster mice, raised in the animal facilities of the Centro de Pesquisas Gonçalo MonizFIOCRUZ were used. They were maintained in accordance with the ethical guidelines established by the Ethical Committee for the Use of Experimental Animals (Comissão de Ética no Uso de Animais - CEUA-CPqGM-FIOCRUZ).

The experimental mice weighed 10-20g and were successively inoculated with strains of $T$. cruzi of three different biodemes (Types I, II and III). The infected mice were evaluated with respect to parasitemia, mortality, and histopathological lesions. Identification and recuperation of the different inoculated strains were performed.
First inoculation: 120 mice were inoculated intraperitoneally with the Colombian strain of $T$. cruzi (Biodeme Type III; T. cruzi I). The inoculum was of $5 \times 10^{4}$ blood trypomastigotes. Infected mice were evaluated during the acute phase of infection with respect to parasitemia and cumulative mortality. Twenty one mice with single chronic infection with the Colombian strain were killed and submitted for histopathological study 50, 80 and 130 days post-infection. Histopathology of 18 mice killed in the acute phase was not included in the present study. Mortality in the acute phase was 23 infected mice. Excluding those that died spontaneously and the animals sacrificed for study, a total of 58 surviving mice infected with Colombian strain were used for reinfection. Table 1 summarizes the distribution of the experimental groups.

\begin{tabular}{|c|c|c|c|c|c|}
\hline Inoculations & T. cruzi strains ${ }^{(*)}$ & \# Mice & Mortality & Histopat. & Survivors \\
\hline \multicolumn{6}{|l|}{ 1st inoculation } \\
\hline & Colombian & 120 & 23 & $39^{(* *)}$ & 58 \\
\hline \multicolumn{6}{|l|}{ 2nd inoculation } \\
\hline 1st Group & $\mathrm{Col}+21 \mathrm{SF}$ & 38 & 1 & 5 & 32 \\
\hline 2nd Group & $\mathrm{Col}+\mathrm{Y}$ & 20 & 1 & 9 & 10 \\
\hline \multicolumn{6}{|l|}{$3^{\text {rd }}$ inoculation } \\
\hline 1st Group & $\mathrm{Col}+21 \mathrm{SF}+\mathrm{Y}$ & 32 & 1 & 31 & - \\
\hline 2nd Group & $\mathrm{Col}+\mathrm{Y}+21 \mathrm{SF}$ & 10 & 0 & 10 & - \\
\hline \multicolumn{6}{|c|}{$\begin{array}{l}\text { (*) Y strain - Biodeme Type I (Z2b). 21SF strain - Biodeme Type II (T. cruzi II). } \\
\text { Col - Colombian strain - Biodeme Type III (T.cruzi I) }\end{array}$} \\
\hline
\end{tabular}

Second and third inoculations: 50 days after the first infection with the Colombian strain the 58 surviving animals were divided into two groups that differed in the sequence of inoculations, i.e. $1^{\text {st }}$ Group was first reinoculated with the 21 SF strain followed by the $Y$ strain; $2^{\text {nd }}$ Group was first reinoculated with the $Y$ strain, followed by the 21SF strain.

$1^{\text {st }}$ Group - 38 mice were reinoculated on the $50^{\text {th }}$ day postinfection with the 21 SF strain (Biodeme Type II, T. cruzi II). After reinfection 1 mouse died spontaneously and 5 were sacrificed for histopathology. Twenty days later the 32 surviving mice were reinfected with the $\mathrm{Y}$ strain (Biodeme Type I, Z2b). At the end of the experiments, 5 mice with double infection and 31 mice with triple infection were studied (Table 1).

$2^{\text {nd }}$ Group - 20 mice (infected with the Colombian strain) were reinoculated with the $Y$ strain on the $50^{\text {th }}$ day post-infection. After reinfection 1 mouse died spontaneously and 7 were sacrificed for histopathology. Thirty days later, 10 mice were reinfected with the 21SF strain. At the end of experiment 10 mice with triple infection were studied.

Control groups with single infection: 20 mice inoculated with the 21 SF strain and 20 mice inoculated with the Y strain.

The inocula for all the groups were of $5 \times 10^{4}$ blood trypomastigotes, obtained from mice infected with the different strains maintained in the laboratory by successive passages. After each reinoculation the mice were evaluated in respect to parasitemia and mortality. 
Histopathological study. From each of the groups, with either a single infection of each strain or double infected and triple infected, mice were killed by exsanguination after anesthesia.

From each mouse, the blood was collected for hemoculture. Complete autopsies were performed and several organs were fixed into $10 \%$ buffered formalin. The tissues were embedded into paraffin and $5 \mathrm{Pm}$ sections, stained with hematoxylin and eosin were obtained for histopathological study. Table 1 shows the number of mice sacrificed from each group.

Morphometric evaluation: quantitative evaluation of the inflammatory infiltrates of the heart and skeletal muscles was performed on the histopathological sections obtained from 9 mice with single chronic infection with the Colombian strain and from 7 mice with triple infection in the $1^{\text {st }}$ group and 8 mice in the $2^{\text {nd }}$ group (Figure 2). The number of mononuclear cells of the inflammatory infiltrates was counted in five microscopic fields of $12 \mathrm{~mm}^{2}$, non successively, using an ocular lens $10 \mathrm{X}$ and an objective 40X (total area of $60 \mathrm{~mm}^{2}$ ). For all semi-automated morphometry, a light microscope (Zeiss) was used and the images were captured and evaluated using the program Axio Vision 3.1(1998-2002) Carl Zeiss Vision GmbH (Zeppelinstrasse 4-88553999 Munchen-Halbergnoss, Germany). Statistical analysis - nonparametric ANOVA and Dunnett's multiple comparative tests were applied. Results were considered significant when determinations reached $\mathrm{p}<0.05$.

Isoenzyme characterization: was performed according to Miles et a ${ }^{19}$ using the culture forms obtained after hemoculture in Warren medium of the blood of mice sacrificed in all groups, with single, double and triple infections. Parasites from the cultures were washed four times with centrifugation at $2,000 \mathrm{~g}$ in buffer tris-KRT pH 7.3 and enzymic extracts were prepared and stored in liquid nitrogen as "pearls". The following isoenzymes were tested: alanine aminotransferase (ALATE.C.2.6.1.2); aspartate aminotransferase (ASAT-E.C.2.6.1.1); glucose-phosphate isomerase (GPI-E.C.5.3.1.9); phosphoglucomutase (PGM-E.C.2.7.5.1). Electrophoresis was performed according to the method of Miles et $\mathrm{al}^{19}$.

Reisolation and identification of the inoculated strains. For the re-isolation of the strains of different biodemes, inocula were obtained from mice with chronic triple infection and injected into suckling mice. From these infected mice, inocula were obtained and injected into three different groups of weaning mice with the objective of reisolating each inoculated strain. For that, four passages into weaning mice were performed for the separate groups every $7^{\text {th }}$ day (for reisolation of the Y strain), every $14^{\text {th }}$ day (for reisolation of the $21 \mathrm{SF}$ strain) and every $30^{\text {th }}$ day (for the Colombian strain), respectively.

Parasitemia and cumulative mortality: were evaluated for each group. Histopathological study: three mice were killed (from each group) on the $7^{\text {th }}, 10^{\text {th }}, 14^{\text {th }}, 20^{\text {th }}$ and $30^{\text {th }}$ days post-inoculation. Fragments of heart and skeletal muscle were fixed into buffered $10 \%$ formalin and embedded into paraffin. 5Pm sections stained with hematoxylin and eosin were examined.

\section{RESULTS}

Parasitemia profiles of mice with the first infection by the Colombian strain, followed by reinoculations with the Y strain and 21 SF strain are shown in Figure 1. No reactivation of parasitemia was detected after reinoculations.

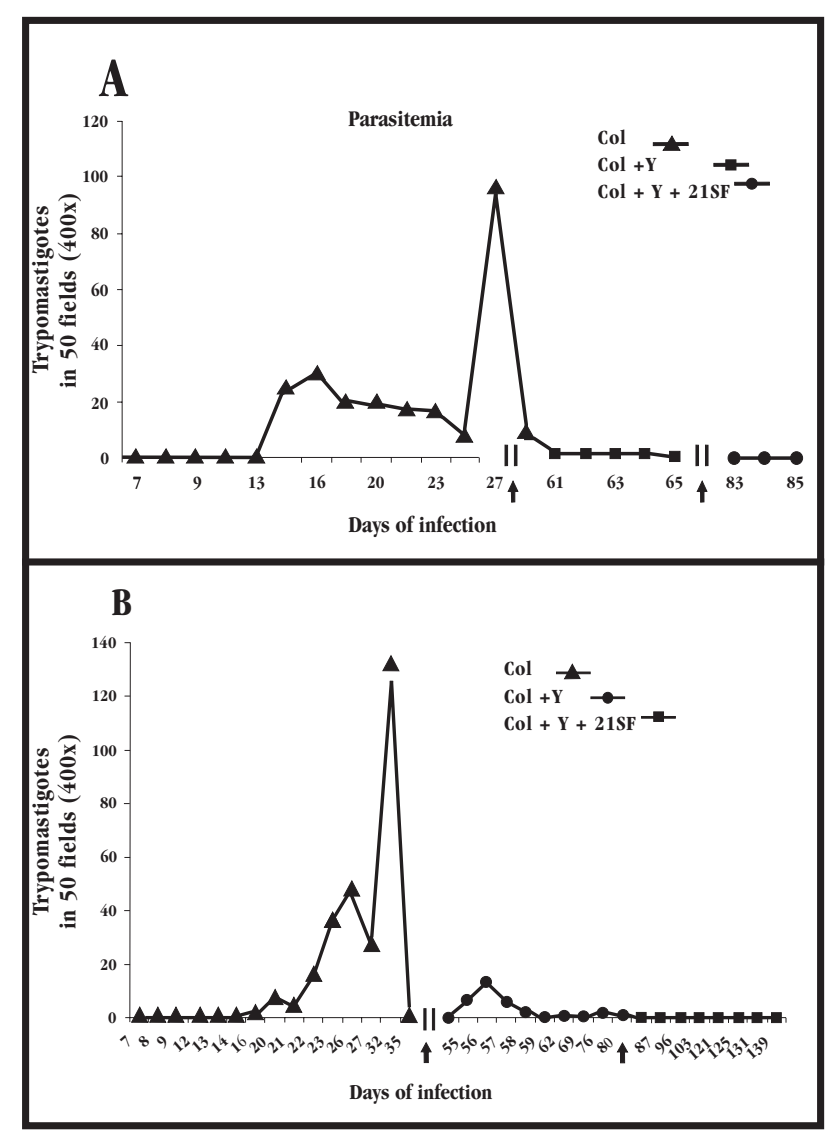

Figure $1-A$ and $B$ - Parasitemia followup in mice that were submitted to three successive infections with different strains of T. cruzi. A Group 1 (ColSFY)- the first infection (Colombian strains) determined an increase in parasitemia from the $16^{\text {th }}$ day of infection with a peak on the $27^{\text {th }}$ day; reinfection with the $21 S F$ strain on the $50^{\text {th }}(\uparrow)$ day did not alter parasitemia as well as reinfection with the $Y$ strain on the $70^{\text {th }}(\uparrow)$ day from the first infection and 20 days after the second reinfection. B - Group 2 (ColYSF) - first infection with the Colombian strain: parasitemia increased from the $20^{\text {th }}$ day, with peak on the $35^{\text {th }}$ day of infection. Second infection with the $Y$ strain on the $50^{\text {th }}(\uparrow)$ day, course with a slight increase in parasitemia; the third infection with $21 S F$ strain on the $30^{\text {th }}(\uparrow)$ day after the second infection and 80 days from the first infection, did no alter the parasitemia.

Mortality. Table 1 represents the number of mice that spontaneously died in the course of infections.

Isoenzyme profiles: enzymic extracts obtained from parasites isolated by hemoculture from mice with triple infection - were submitted for electrophoretic analysis for GPI, PGM, ALAT and ASAT (Table 2).

$\mathbf{1}^{\text {st }}$ Group (Table 2). The profiles of GPI and PGM, from 4 samples obtained from mice with triple infection (identified as $820,821,823,824)$, represent the patterns of zimodeme Z2b (Biodeme Type I); in one sample (identified as 867), the pattern of the zymodeme Z1 (Biodeme Type III) was revealed (Figures $2 \mathrm{~A}, \mathrm{~B}$ ). 
Table 2 - Isoenzyme patterns from enzymic extracts obtained by hemoculture from mice with triple infection with different strains of Trypanosoma cruzi*

\begin{tabular}{lcccrr}
\hline & \multicolumn{5}{c}{ Isoenzymes } \\
\cline { 2 - 6 } Enzymic Extracts & Mice Ident & GPI & PGM & ALAT & ASAT \\
\hline 1st group & & & & & \\
1 & 820 & Z2b & Z2b & Z1 & Z2b \\
2 & 821 & Z2b & Z2b & Z2b & Z2 \\
3 & 823 & Z2b & Z2b & Z2b & Z2 \\
4 & 824 & Z2b & Z2b & Z2b & Z2 \\
5 & 867 & Z1 & Z1 & np & np \\
2nd + group & & & & & \\
6 & 882 & Z2b & Z2b & Z1 & Z2 \\
\hline
\end{tabular}

1st group $(\mathrm{Col}+21 \mathrm{SF}+\mathrm{Y})$ and 2nd group $(\mathrm{Col}+\mathrm{Y}+21 \mathrm{SF})$

$\mathrm{np}=$ not performed

*Y strain - Biodeme Type I (Z2b). 21SF strain - Biodeme Type II (T. cruzi II).

Col - Colombian strain - Biodeme Type III (T.cruzi I)
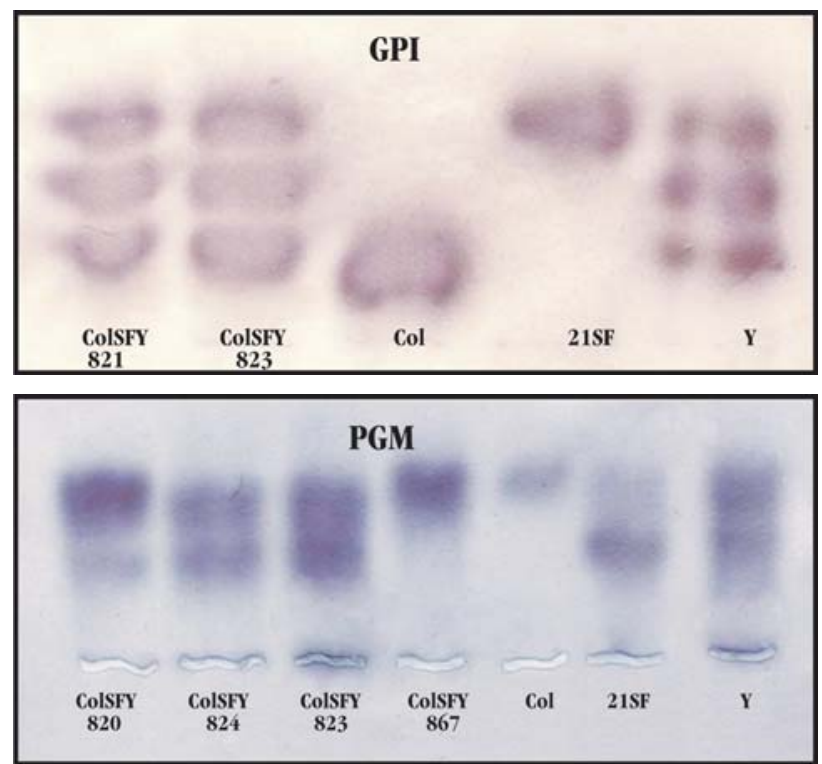

Figure 2 - $A$ and B - Isoenzyme profiles of GPI and PGM. A - GPI : ColSFY, samples 821 and 823 and the prototypes of the zimodemes: Col (Z1), $21 S F(Z 2), Y(Z 2 b)$. Patterns from the samples 821 and 823 correspond to the $Y$ strain (Z2b). B - PGM - ColSFY-samples 820, 824, 823, 867 and the prototypes of the Biodemes: Col (Z1), 21SF(Z2), Y(Z2b). Patterns from the samples 820, 824, 823 represented the $Y$ strain (Z2b). The sample 867 showed the profile of the Colombian strain (Z1).

The profiles of ALAT for 3 samples $(821,823,824)$ represent the zymodeme Z2b (Biodeme Type I). One sample (820) showed the profile of Z1 (Biodeme Type III) (Figure $3 \mathrm{~A}$ ).

The patterns of isoenzyme ASAT for samples 821,823 , 824 , revealed the profile of zymodeme Z2 (Biodeme Type II) and for sample 820, the profile of $\mathrm{Z} 2 \mathrm{~b}$ (Figure 3B).

$2^{\text {nd }}$ Group (Table 2). The isoenzyme profiles from culture forms obtained from one mouse with triple infection (sample 822), revealed for GPI and PGM revealed the pattern of zymodeme Z2b (Biodeme Type I). The enzyme ALAT revealed the pattern of zymodeme Z1 (Biodeme Type III) and the enzyme ASAT showed the pattern of Z2 (Biodeme Type II).

Histopathology. Inflammatory lesions in the myocardium and skeletal muscles were evaluated semi-quantitatively as absent $(0)$, mild $(+)$ moderate $(++)$ or intense $(+++)$.

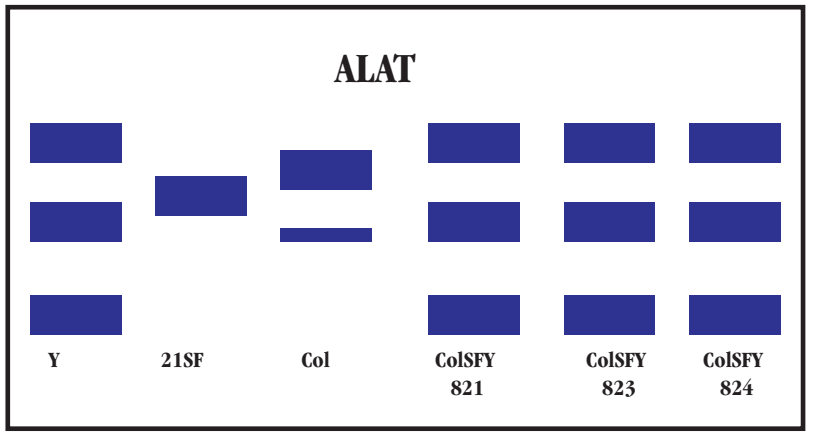

A

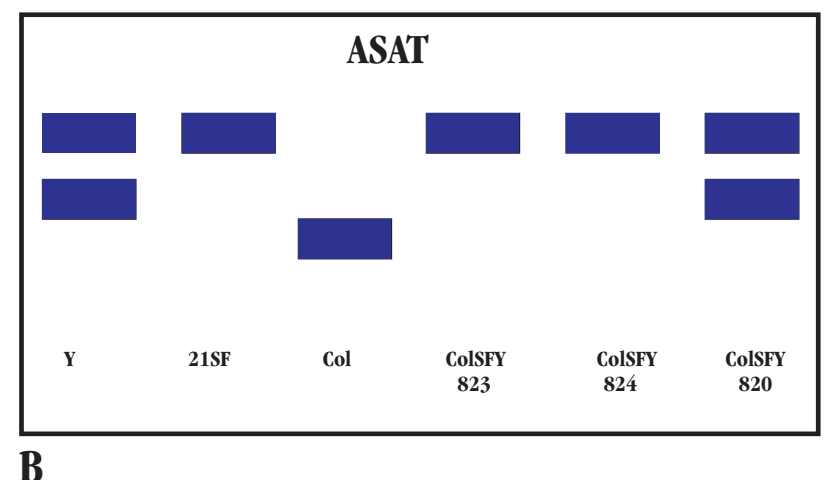

Figure 3 - $A$ and $B$ - Isoenzyme profiles for ALAT and ASAT. Group 1 ColSFY. A - ALAT: prototypes of the different biodemes: Y (Z2b), $21 S F$ (Z2), Colombian (Z1);samples ColSFY - 821, 823, 824, showed the pattern of the $Y$ strain (Z2b). B-ASAT-prototypes of the biodemes and samples ColSFY - 823 and 824. Both samples showed the profile of the $21 S F$ strain (ZII); sample 820 disclosed the profile $\mathrm{Z2b}$.

Single infection with the Colombian strain (mice in the chronic phase of infection). Myocardium (Figures 4 A,B) - from the $50^{\text {th }}$ to the $130^{\text {th }}$ day post-infection, in most of the cases, mild $(+)$ or moderate $(++)$ diffuse inflammatory infiltrates were seen in most cases predominantly in the atrial myocardium, in the absence of parasites. Skeletal muscle (Figures 4 C,D) - inflammatory infiltrates were absent in a few cases and varied from mild to moderate in the majority, occasionally associated with the focal destruction of muscle cells in the absence of parasites. None of the mice showed intense lesions either in the myocardium or the skeletal muscles.

Single infection with the Y strain (mice did not survive until the chronic phase) On the $10^{\text {th }}$ day of infection, the presence of intracellular amastigotes in the cardiac fibers without inflammation was registered. Focal inflammatory infiltrates and scarce intracellular parasites were present in the skeletal muscles.

Single infection with the 21SF strain (mice did not survive until the chronic phase). Twenty to 30 days after infection, an inflammatory process varying from moderate to intense was present in the myocardium and skeletal muscle, related to the presence of disintegrated intracellular parasites.

Double infections. Colombian strain plus Y strain. Mice were studied at two points after reinfection (63 and 84 days post infection with the Colombian strain, plus 13 and 34 days post-infection with the $\mathrm{Y}$ strain): the myocardium 


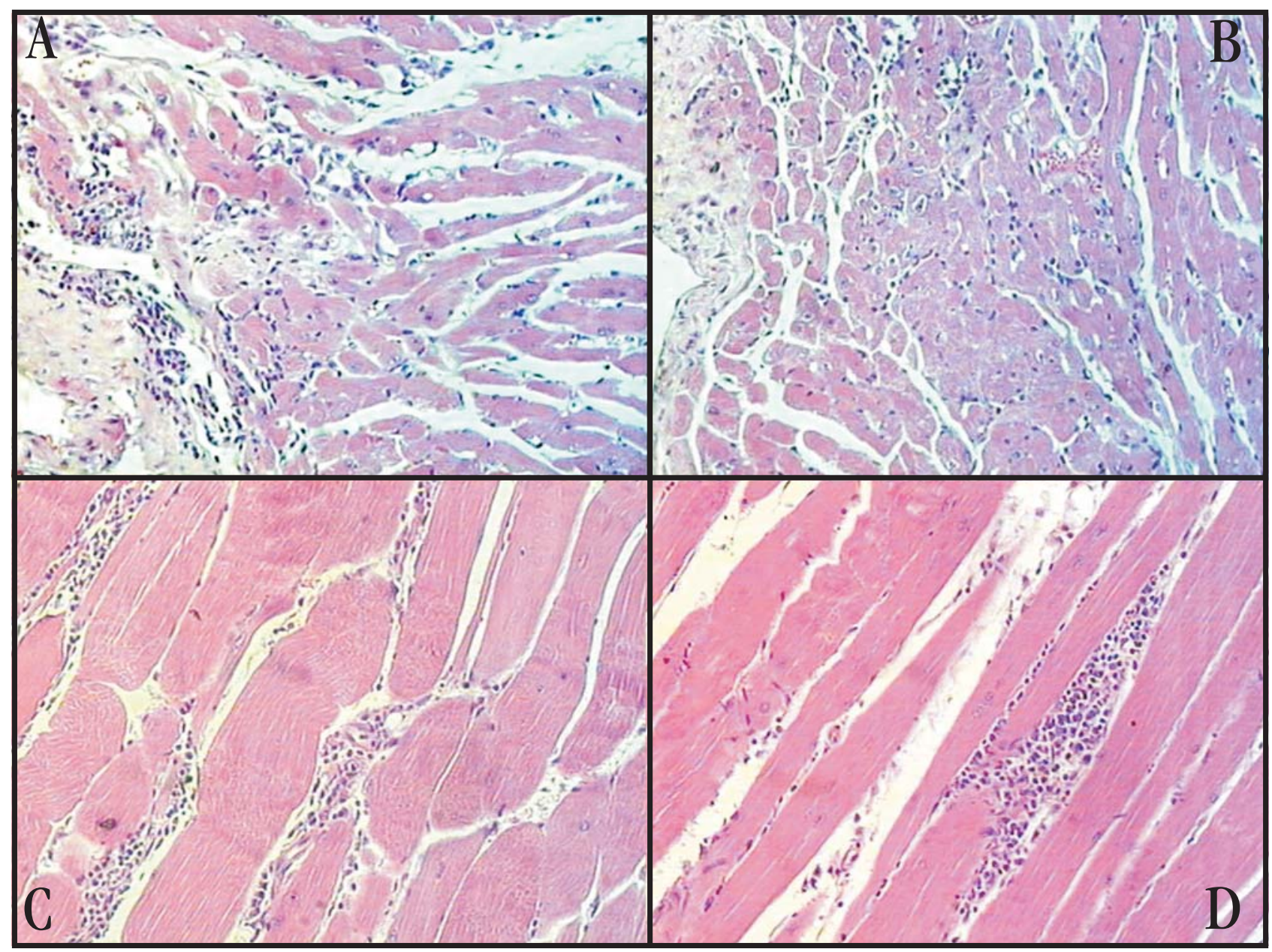

Figure $4-A, B, C, D$-Sections of the myocardium and skeletal muscles from mice chronically infected with the Colombian strain (single infection); $A$ and $B$-myocardium - interstitial infiltration with mononuclear cells and small areas of focal infiltration $100 X$. C and $D-s k e l e t a l$ muscle interstitial infiltration with mononuclear cells showing areas of myocell destruction. $(\mathrm{C}-400 \mathrm{X}, \mathrm{D}-200 \mathrm{X})$.

and skeletal muscles showed mild to moderate focal and diffuse inflammatory infiltrates. Compared to single infection with the Colombian strain, slight exacerbation of the inflammatory lesions of the myocardium and skeletal muscles, was were observed in the reinfected mice.

Double infection with the Colombian strain $(80$ days) and 21 SF strain (30 days) : focal and diffuse mild to moderate inflammatory infiltrates in the myocardium and skeletal muscles were present, in the absence of parasites. Lesions seen in the cases with double infection did not differ from those seen in the mice with single chronic infection with the Colombian strain.

Triple infection - $\mathbf{1}^{\text {st }}$ group (Col-SF-Y). The duration of infection for each strain was as follows - Colombian strain: 100 to 115 days; 21SF strain: 50 to 65 days; Y strain: 30 to 45 days.

Myocardium (Figures 5 A,B) - Focal inflammatory lesions varied from mild $(+)$ to moderate $(++)$ or intense $(+++)$. Focal necrosis of non-parasitized myocardiocytes was present, with dense mononuclear cell infiltration, predominantly in the atria. Necrosis of myocells containing disintegrated parasites was also seen, with polymorphonuclear neutrophil infiltration. The lesions were intense $(+++)$ in $45 \%$ of cases.
Skeletal muscles. In some cases small mononuclear inflammatory infiltrates were present concomitantly with mild diffuse infiltration, in the absence of parasites. In $30 \%$ of cases, intense focal and diffuse inflammatory infiltrates were present, with necrosis of parasitized myocytes, in the presence of parasites in disintegration, with infiltration by polymorphonuclear neutrophils.

Conclusion. A clear intensification of the inflammatory lesions in the myocardium and skeletal muscles was demonstrated in mice with triple sequential infection with the Colombian $+21 S F+Y$ strains, when compared with mice with chronic single infection with the Colombian strain or with double infection with the Colombian and 21 SF strains with higher incidence in the myocardium (45\%) than in the skeletal muscles $(30 \%)$.

Triple infection - $2^{\text {nd }}$ group (Col-Y-SF). The duration of infection with each strain was as follows: Colombian strain,141 and 150 days; Y strain, 91 and 100 days; 21 SF strain, 57 and 66 days.

Myocardium. Mice with triple infection presented mild $(+)$ focal inflammatory infiltrates or moderate $(++)$ focal confluent inflammatory lesions. None of the cases showed 
intense lesions in the myocardium or absence of lesions. Skeletal muscle (Figures 5 C, D) - Lesions varied from mild $(+)$ to intense $(+++)$ and were represented by focal or diffuse mononuclear cell infiltration, in the absence of parasites. Focal necrosis of skeletal myocells was present, frequently showing calcification. Moderate to intense lesions, were present in the majority (75\%) of cases.

Conclusion. In mice with triple infection with the Colombian $+\mathrm{Y}+21 \mathrm{SF}$ strains of $T$. cruzi, a clear intensification of the skeletal muscle lesions was detect, as compared with the group with single infection with the Colombian strain. Cardiac lesions were comparable in the two groups although in the mice with triple infections no one case was registered showing an absence of lesions.

Morphometric evaluation of inflammatory lesions. Figures $6 A$ and $B$ show the results of morphometric evaluation of the inflammatory infiltrates in the myocardium and skeletal muscles of mice with triple infection with strains of $T$. cruzi of different biodemes as compared with mice with single chronic infection with the Colombian strain. The results for the $\mathbf{1}^{\text {st }}$ group (Col-SF-Y) showed a significant $(\mathrm{p}<0.05)$ increasing in the number of inflammatory cells in the myocardium. There was also an augmentation of inflammatory cells in the skeletal muscle, although without statistical significance $(\mathrm{p}>0.05)$, (Figure $6 \mathrm{~B})$.

$2^{\text {nd }}$ group (Col-Y-SF), a significant $(\mathrm{P}<0.01)$ increase in inflammatory cells in the skeletal muscle was detected (Figure 6B). An increase in inflammatory infiltrates was also observed in the myocardium, although without statistical significance $(\mathrm{p}>0.05)$, (Figure 6A).

Results of reisolation of the inoculated strains. Parasitemia of the three groups of mice in which reisolation and subsequent passages were perfomed showed the parasitemia profiles of Biodeme Type I for the passages performed on the $7^{\text {th }}$ day of infection; the Biodeme Type II profile of parasitemia was seen in those submitted for passages on the $14^{\text {th }}$ day and the Biodeme Type III profile of parasitemia for the isolates of passages performed every $30^{\text {th }}$ day (Figure 7 ).

Histopathology of the groups of reisolation. Inocula obtained after passages performed every seven days in mice, determined lesions characteristic of biodeme Type I with typical macrophagotropism and the presence of myocarditis in the early phase of infection. Mice that received the inoculum obtained after passages performed every 14 days

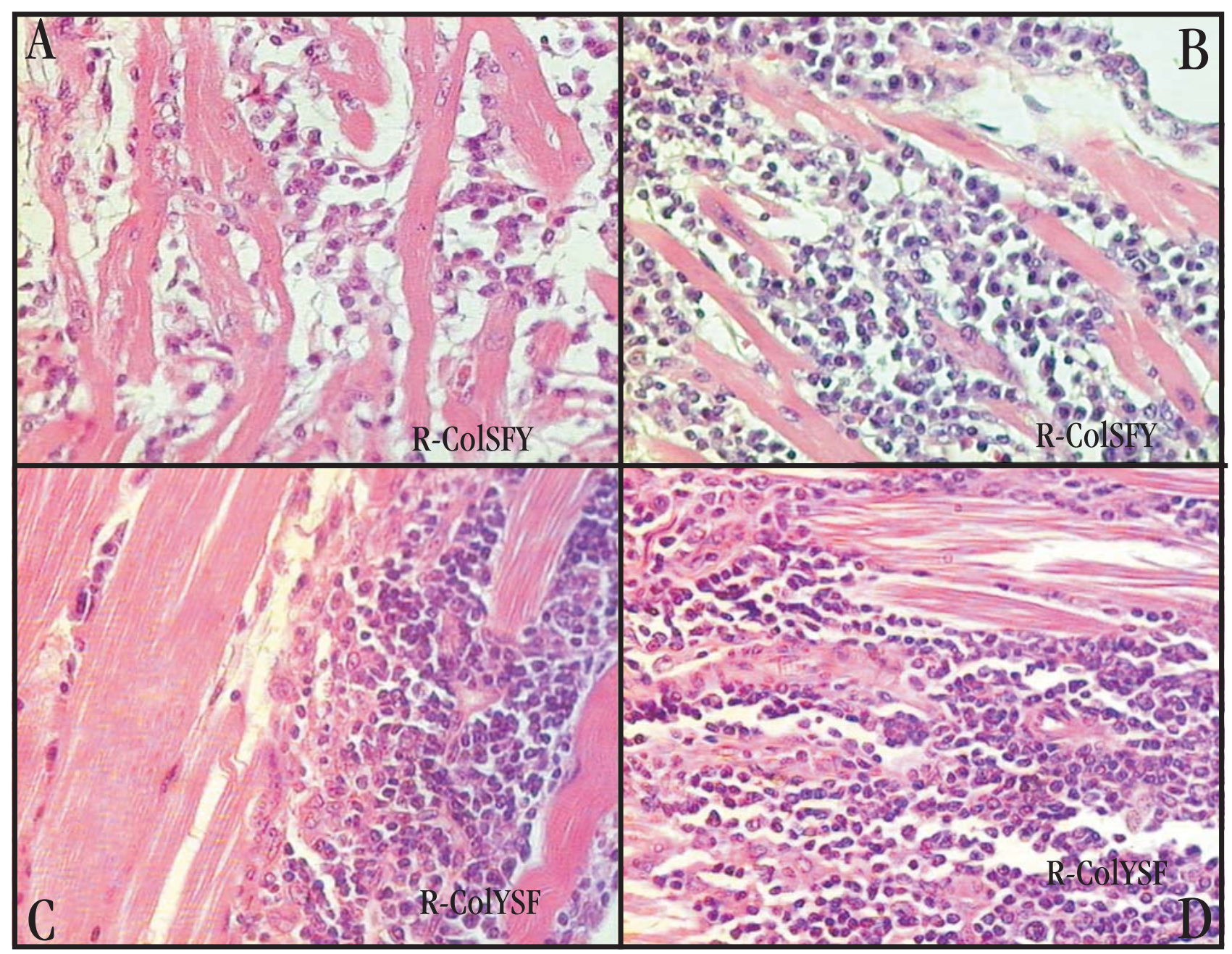

Figure 5 - A, B, C, D - Sections of the myocardium and skeletal muscles from mice with triple infection ; A and B - Group 1 (ColsFY) - sections of the myocardium showing extensive destruction of cardiac cells and substitution by dense inflammatory infiltration, corresponding to intense $(+++)$ lesions. 200X. $C$ and $D-$ Group 2 (ColYSF) -skeletal muscle sections showing extensive areas of muscle cell destruction and the presence of intense $(+++)$ inflammatory infiltrations $(C-400 \mathrm{X}$ and $\mathrm{D}-200 \mathrm{X})$. 


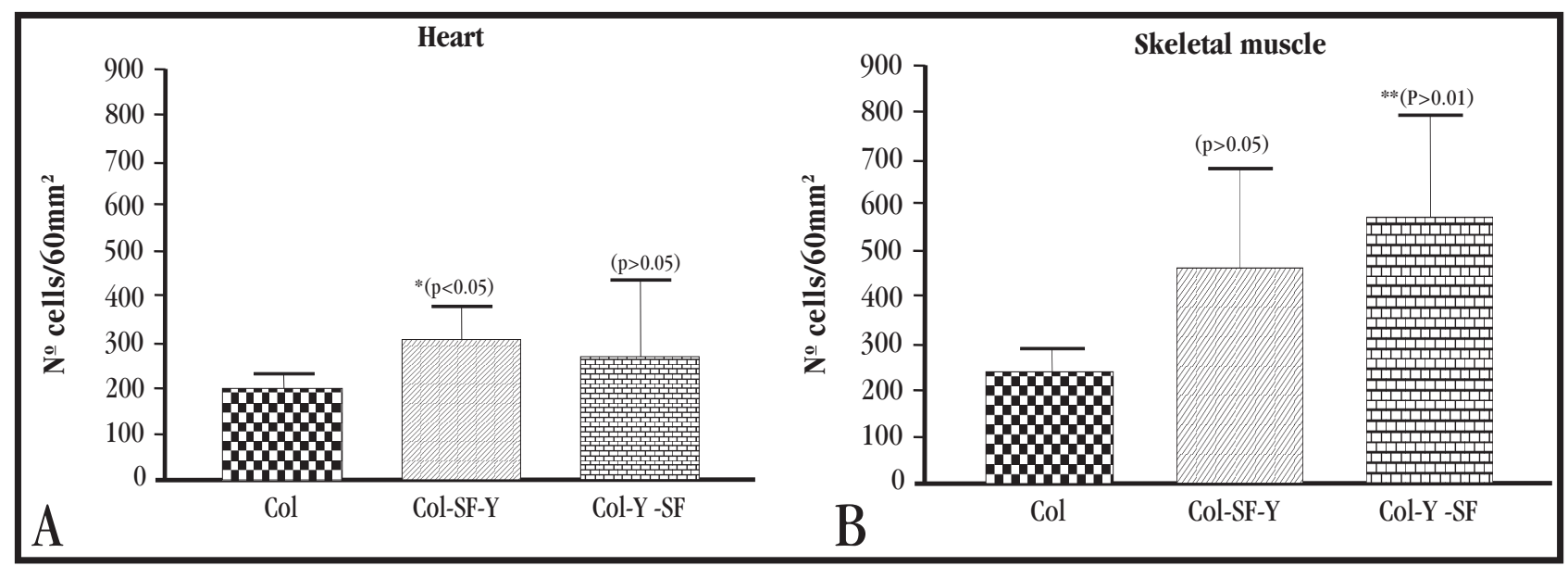

Figures 6 - A, B - Morphometry of inflammatory infiltrates. A-Heart of mice with triple infection, from the 1st group (Col-SF-Y) and 2nd group (Col-Y-SF) as compared with the single chronic infection (Col): for the 1st group a significant increase in the number of inflammatory cells was detected in the myocardium ( $p<0.05$ ); for the 2nd group, although showing a higher number of cells, the difference was not statistically significant ( $>0.05)$. B - Skeletal muscle of mice with triple infection: 1st group (Col-SF-Y)- increased number of inflammatory cells, without statistical significance (p>0.05). 2nd group (Col-Y-SF)- significant increase in the number of inflammatory cells as compared with the single infection group (Col) ( $p<0.01)$.

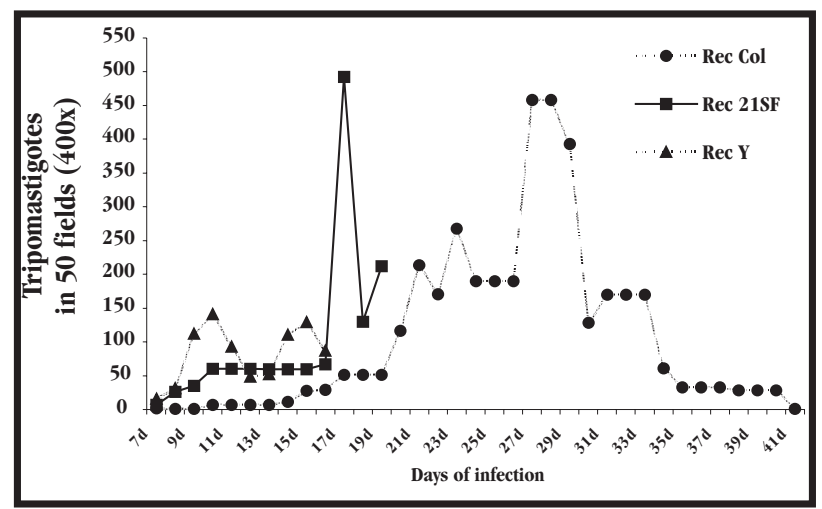

Figure 7 - Parasitemia of the experimental groups of reisolation of the three strains by successive passages into mice, of the blood from mice with triple infection, as follows: passages on the $7^{\text {th }}$ day - parasitemia peak at on the $9^{\text {th }}$ day, characteristic of the $Y$ strain; passages on the $14^{\text {th }}$ day - parasitemia peak on the $17^{\text {th }}$ day, reproducing the profiles of the 21SF strain. Passages on each $30^{\text {th }}$ day-parasitemia profiles of the Colombian strain on the $29^{\text {th }}$ day.

showed evident myocardiotropism and myocarditis, characteristic of the biodeme Type II. In the group of mice inoculated after passages performed every $30^{\text {th }}$ day of infection, predominance of skeletal muscle parasitism with necrosis of parasitized myocells as well as the presence of myocarditis, characteristic of the biodeme Type III, were present.

These results indicate that a selection of each strain was obtained, confirming the persistence of parasites from each inoculation.

\section{DISCUSSION}

The importance of reinfections in cardiac morbidity of Chagas disease, has been suggested by clinical observations ${ }^{1316}$. Recently, Dias et $a l^{14}$ performed an extensive revision on the impact of Chagas' disease control in Latin America, by the elimination of domestic vectors and transfusional transmission. A reasonable reduction of morbidity and of precocious mortality due to infection with T. cruzi was detected. The conclusion is that, multiple reinfections in endemic areas could be considered an important factor in the morbidity of Chagas disease and that the rupture of this chain, by vector control has positively influenced the evolution of the disease.

Previous experimental studies have demonstrated, either through biological characterization ${ }^{2}$ or by schizodeme analysis ${ }^{12}$, the persistence, in the same animal, of two inoculated strains of $T$. cruzi in the same animal. The present study demonstrates that successive infections by $T$. cruzi represent a real risk of exacerbation of inflammatory cardiac lesions in chronically infected mice and the aggravation of tissue lesions in mice with multiple infections. However, it is important to emphasize that the sequence of inoculations of the different strains has a clear influence on the results. Myocarditis and myositis aggravation does not occur simultaneously. As was shown, myocarditis is not intensified when the last infection was realized with the $21 \mathrm{SF}$ strain, although a significant increase in myositis was detected. In contrast, when the last infection was performed with the $Y$ strain, a significant intensification in myocarditis was observed. Although myositis was also intensified this was not statistically significant. Since the $Y$ strain is highly virulent and shows rapid parasite multiplication, its virulence and pathogenicity could be responsible for the degree of lesions precociously observed after the last infection, predominantly affecting the myocardium. Tissue tropism could also be considered an important factor in the determinism of lesions and it is possible that the last inoculated strain predominates either in the myocardium or skeletal muscles.

In the present study, confirmation of the coexistence of three strains in the same mouse was performed by the isoenzyme profiles of ALAT, ASAT, PGM and GPI which distinguish the three biodemes ${ }^{5}$. Interestingly, enzymic extracts obtained through hemoculture from the blood of the same triple infected mice, revealed the zymodeme Z2b (Biodeme Type I), for the enzymes GPI and PGM, Zymodeme 
1 (Biodeme Type III) for the enzyme ALAT and zymodeme Z2 (Biodeme Type II) for the enzyme ASAT. This result indicates concomitant infection with the three strains, although each one was revealed through a different isoenzyme. Furthermore, the three strains of the successive inoculations were reisolated and the characteristic lesions and histotropism of the different biodemes, each maintaining the biological characteristics of the original strain, were determined in suckling mice.

These findings have clear implications in the unsuccessful attempts at vaccine development using attenuated or killed parasite forms, by several authors ${ }^{711} 16171820222324$ since even the patent infection does not vaccinate against $T$. cruzi infections.

The increase in inflammatory lesions was not accompanied by an exacerbation of parasitism. However these lesions became intense and confluent, with macrophages and histopathological characteristics of cellular immunological response.

It is known that chronically infected mice develop a mechanism of delayed type hypersensitivity response, as reviewed by Reis ${ }^{21}$. This response probably controls parasitic proliferation and maintains the host/parasite equilibrium, with subpatent parasitemia. Characteristic focal and perivascular mononuclear inflammatory infiltrates are present in the heart and skeletal muscles, and focal necrosis of non-parasitized myocells is present. Aggravation of delayed type hypersensitivity lesions can occur by interference with the immunological mechanisms. In dogs chronically infected with $T$. cruzi, the cardiac lesions were aggravated by the use of cyclophosphamide in low doses, which interferes in the immunological network, as has been shown by Andrade et $\mathrm{al}^{6}$.

The possibility that successive inoculations could influence the mechanisms of immunological response in the mouse model can not be discarded.

Additionally, the hypothesis that multiple infections potentiate and intensify the inflammatory response, could be considered as one explanation of the results obtained in the present study, which showed an intensification of the lesions found in mice with triple infection. A cumulative effect produced by the infection with $T$. cruzi strains that differed in their tropism and pathogenicity could be present, considering the aggravation of the inflammatory lesions and their predominance either in the myocardium or skeletal muscles, depending on the sequence of inoculations.

\section{REFERENCES}

1. Andrade SG. Caracterização de cepas do Trypanosoma cruzi isoladas no Recôncavo Baiano. Revista de Patologia Tropical 3:65-121, 1974.

2. Andrade SG, Carvalho ML, Figueira RM, Andrade ZA. Recuperação e caracterização de tripomastigotas inoculados em animais imunes (Reinoculação com diferentes cepas do T. cruzi). Revista do Instituto de Médicina Tropical de São Paulo 12: 395-402, 1970.

3. Andrade SG, Figueira RM, Andrade Z.A. Influência de infecções repetidas no quadro histopatológico da doença de Chagas experimental. Gazeta Médica da Bahia 68: 115-123, 1968
4. Andrade SG, Magalhães JB. Biodemes and zymodemes of Trypanosoma cruzi strains: correlations with clinical data and experimental pathology. Revista do Instituto de Medicina Tropical de São Paulo 30: 27-35, 1997.

5. Andrade V, Brodskyn C, Andrade SG. Correlation between isoenzyme patterns and biological behavior of different strains of Trypanosoma cruzi. Transaction of the Royal Society of Tropical Medicine and Hygiene 77: 796-799, 1983

6. Andrade ZA, Andrade SG, Sadigursky M. Enhancement of chronic T. cruzi myocarditis in dogs treated with low doses of cyclosphosphamide. American Journal of Pathology 127: 467-473, 1987.

7. Basombrio MA, Segura MA, Moura MC, Gomez L. Field trial of vaccination against American Trypanosomiasis (Chagas' disease) in dogs. American Journal of Tropical Medicine and Hygiene 49: 143-151, 1993.

8. Brener Z. Alguns aspectos da imunidade adquirida em camundongos experimentalmente inoculados com Trypanosoma cruzi. Revista do Instituto de Medicina Tropical de São Paulo 9: 233-238, 1967.

9. Brumpt E. Immunitë partielle dans les infections à Trypanosoma cruzi, transmission de ce trypanosome par Cimex rotundus. Rôle régulateur des hotes intermédiaires. Passage à travers la peau. Bulletin de la Societe de Pathologie Exotique 6: 172-176, 1913.

10. Chagas C. Nova entidade mórbida do homem. Brazil Médico 24: 423-428, 1910.

11. Culbertson JT, Kolodny MH, Maxwell H . Acquired immunity in rats against Trypanosoma cruzi. Journal of Parasitology 24: 83-90, 1938

12. Deane MP, Souza MA, Pereira NM, Gonçalves M, Momem H, Morel CM. Trypanosoma cruzi: inoculation schedules and re-isolation methods selected individual strains from doubly infected mice, as demonstraded by schizodeme and zymodeme analysis. Journal of Protozoology 31: 276-180, 1984

13. Dias E. Os efeitos da super-infecção sobre a evolução da cardiopatia crônica chagásica. Revista Goiana de Medicina 9: 233-239, 1963.

14. Dias JCP, Silveira AC, Schofield CJ. The impact of Chagas disease control in Latin-America - A Review. Memórias do Instituto Oswaldo Cruz 97: 603-612, 2002.

15. Macedo VO. Influência da exposição à reinfecção na evolução da Doença de Chagas (Estudo longitudinal de cinco anos). Revista de Patologia Tropical 5: 33-116, 1976.

16. McHardy H. Immunization of mice against Trypanosoma cruzi. The effect of size of dose, and route of injection, of immunizing and challenge inocula. Tropenmedicine and Parasitology 28: 11-16, 1977.

17. Menezes H. Active immunization of mice with the avirulent $Y$ strain of Trypanosoma cruzi against heterologous virulent strain of the same parasite. Revista do Instituto de Medicina Tropical de São Paulo 11: 335-342, 1969a.

18. Menezes H. Active immmunization of dogs with a non virulent strain of Trypanosoma cruzi. Revista do Instituto de Medicina Tropical de São Paulo 11: 258-263, 1969b

19. Miles MA. Further enzyme characters of Trypanosoma cruzi and their evaluation for strain identification. Transaction of the Royal Society of Tropical Medicine and Hygiene 74:221-237, 1980.

20. Paiva CN, Castelo-Branco MT, Rocha JÁ, Lannes-Vieira J, Gattass CR. Trypanosoma cruzi: lack of T cell abnormalites in mice vaccinated with live trypamastigotes. Parasitology Research 85: 1012-1017, 1999.

21. Reis G. Cell mediated immunity in experimental Trypanosoma cruzi infection. Parasitology Today 13: 335-340, 1997.

22. Revelli S, Basombrio MA, Valenti JL, Moreno H, Poli H, Morini JC. Evaluation of an attenuated Trypanosoma cruzi strain in rats. Analysis of survival, parasitemia and tissue damage. Medicina (Buenos Aires) 53:39-43, 1993.

23. Ritter DM, Rowland EC. Corpus Christi strain- induced protection to Trypanosoma cruzi infection in $\mathrm{C} 3 \mathrm{H}(\mathrm{He})$ mice: effective dose, time, route and number of vaccinations. Journal of Parasitology 70: 755-759, 1984.

24. Seah S, Marsden PD. The protection of mice against a virulent strain of Trypanosoma cruzi by previous inoculation with an avirulent strain. Anals of Tropical Medicine and Parasitology 63: 211-214, 1969.

25. Torres MC, Tavares MT. Miocardite no macaco Cebus após inoculações repetidas com Schizotrypanum cruzi. Memórias do Instituto Oswaldo Cruz 56:85-118, 1958. 